almost certain to be a fizzle." By "democratic rights" the editorial writer apparently refers to the exclusionary rules of evidence. For once the introduction of testimony began it was around these rules that the trial fizzled. Defense counsel's arguments on the evidence were castigated by one observer as an effort to keep the jury from hearing the case, and as previously pointed out there were hints that defendants were trying to stall the trial until the end of the war. But another reporter in the New York Times praised the objections of defense counsel as a fine example of democracy in action, particularly since more than twenty of the twenty-nine defense attorneys were court-appointed, unpaid, and thus economically injured by any delay in the proceedings. It certainly could not be argued that defense counsel had no right to object to evidence, though if this were deliberately done to delay it would probably be punishable. As one of its officers, an attorney is to aid the court in its determination of a case, but he has also a duty to protect his client by objecting to the introduction of irrelevant or inflammatory material. In accomplishing the latter task counsel also carries out the former, on the assumption that the exclusionary rules aid in the judicial ascertainment of the truth. However, the possibilities of delay inherent in the rules are greatly enhanced if there are numerous defendants. The defendants might have minimized delay by a union of strategy and by the use of a few attorneys to represent all. Had this been done, however, the unification of the defendants in the alleged conspiracy might have been suggested to the jury, which the Government was supposed to have the burden of proving. Thus defense counsel bickered, fought, and objected to each others' statements, and no doubt defendants had the right to adopt these tactics.

The real "villain in the piece" may therefore be the rules of evidence. If based on reasonable assumptions, they may be justified even though they allow a result such as that which occurred here. This may be part of the price we pay for a fair trial even in situations where those seeking the benefit of the rules seek also to destroy that for which the rules stand.

It can reasonably be asked why the Government, at least when defense strategy became clear, did not seek to sever the various cases and move against the defendants individually. Possibly the Government's case against some of the defendants rested on its ability to prove the conspiracy, but it is doubtful whether a result in which some of defendants might have been convicted and others not prosecuted would have been of less value than the fiasco which actually occurred.

\title{
SOLDIERS' AND SAILORS' WILIS: A PROPOSAL FOR FEDERAL LEGISLATION
}

It is said that Julius Caesar, as a temporary measure, first extended to the soldiers in his legions the privilege of disposing of their personal property by informal testament.. By the time of Trajan it had been extended to naval per-

× Swinburne, Testaments and Last Wills, pt. I, §§ I0, I2, I4 (7th ed., I793). 
sonnel on shipboard. ${ }^{2}$ When the Roman legions were no longer primarily engaged in distant conquest, the privilege was limited to soldiers "cum in expeditionibus occupati sunt."3 The Roman law of succession later became highly developed, but the provisions for informal testaments of soldiers and seamen were retained. 4 The reason given for this privilege was that soldiers and seamen were "better acquainted with weapons than with books and their ignorance of the laws of peace [was] proportionate to their skill in arms."s The Roman law permitted a soldier or seaman to make his testament in whatever manner he could. ${ }^{6}$ Even the usual minimum testamentary age requirement did not apply to soldiers and seamen, but it is essential to remember that a male could make a will upon attaining puberty. ${ }^{7}$ The Roman law further provided that a soldier's informal will was valid only if the testator died within one year after discharge. ${ }^{8}$ It required the testimony of two witnesses to prove a soldier's or seaman's will, but this was probably because of the prevailing rule as to minimum proof of any fact, which required two witnesses.9

From this Roman origin the soldiers' and sailors' privilege to make informal testaments spread to civil law jurisdictions as well as to England and America. But before the Statute of Frauds in England ${ }^{\text {to }}$ any testator could bequeath his personalty by oral testament or by an informal unsigned writing.. This was undoubtedly permitted because few people were able to write..$^{\mathrm{I2}}$ It is apparent, therefore, that in the early days of the common law, at least, soldiers and seamen enjoyed no special testamentary privileges not shared by others. However, by the time of James I it was recognized that an informal will was valid only if

2 Ex parte Thompson, 4 Brad. (N.Y.) ${ }_{54}$ (x854); Digest 37.r3.I (I).

3 "It has been said that the Roman law originally embraced every soldier wherever situated, but that the Code of Justinian ultimately limited the exception to soldiers on an expedition or engaged in a battle or siege....." I37 A.L.R. I3IO, at I3II; Gould v. Safford, 39 Vt. 498 (I866); see Summers, Wills of Soldiers and Seamen, 2 Minn. L. Rev. 26I (xgI8).

${ }_{4}$ "If then we are considering whether a testament be valid, we first ought to consider whether he who made it had testamenti factio; then if he had it, we shall inquire whether he made the testament according to the rules of the civil law; except in the case of soldiers who as we have stated on account of their great want of legal knowledge are allowed to make a testament as they will and they can." Gaius 2.xo9-III; Ulpian 23.10; Institutes 2.xx; Digest 29.I, 37.I3; Code 6.2.

5 Swinburne, op. cit. supra note I, pt. I, at \& $x_{4}$; see Page, Wills $\$ \S 383-88$ (I926).

6 "In whatever manner soldiers may have made their testaments, they are valid, that is, even without any legal form. For by certain imperial constitutions they have been privileged to declare their intentions as they will and as they can." Ulpian 23.10; Gaius 2.Ir4.

7 Ulpian 20.12; and see Atkinson, Soldiers' and Sailors' Wills, 28 A.B.A.J. 753 (z942).

8 ". . . but where a soldier has made a testament contrary to the rule of law, it is only valid if he have died either in service or within a year after discharge." Ulpian 23.IO.

9 Digest 22.5.12.

${ }^{10} 29$ Car. II, c. $3, \S 23$ (I677).

"Swinburne, op. cit. supra note I, pt. I, at $\$ \S$ ro, 12.

${ }^{12}$ See Hubbard v. Hubbard, 8 N.Y. 196 (1853). 
made during the last illness of the testator..$^{23}$ All during this time, however, the soldiers' and sailors' privilege was generally recognized. ${ }^{14}$ The Statute of Frauds ${ }^{15}$ stipulated the requirements for the formal execution of a will, but excepted the testaments of soldiers and seamen in these words: "provided always that notwithstanding this act any soldier being in actual military service, or any mariner or seaman being at sea, may dispose of his movables, wages, and personal estate, as he or they might have done before the making of this act." The Wills Act of $I 837^{\mathrm{I} 6}$ enacted this exception in practically the same words, and that of $1918^{17}$ extended the privilege so that soldiers and sailors might also dispose of real estate by informal will. ${ }^{18}$

About three-fourths of the states have statutes granting privileges to soldiers and seamen enabling them to dispose of personal property by informal testament. ${ }^{\text {I9 }}$ Most of these provisions are modeled after the Statute of Frauds; the history, background, and development of the privilege in Roman law and in English common and ecclesiastical law are therefore important in understanding the development in the United States. ${ }^{20}$

It was generally conceded in Rome, England, and America that soldiers of all ranks and grades were entitled to the privilege. Under Roman law even the secretaries and orderlies of officers, and camp followers had the privilege when "on expedition." In the case of seamen the Roman law extended the privilege only to members of the naval forces and then only when on shipboard.22 After passage of the Statute of Frauds, England and the commercial countries of the continent relaxed the requirements and extended the privilege to merchant seamen as well as members of the navy. Later cases involving the informal testaments of seamen have generally restricted the privilege to cases where the testator was "at sea," although a Michigan statute requires only that the testator be "on shipboard." "There has been some conflict as to whether "at sea" means only the high seas and tidal waters or whether the Great Lakes and navigable rivers are included. ${ }^{24}$

${ }_{3}$ Prince v. Hazleton, 20 Johns. (N.Y.) 502 (I822).

${ }_{4}$ Swinburne, op. cit. supra note I, pt. I, at $\S I_{4}$.

${ }^{15} 29$ Car. II, c. $3, \S 23$ (I677).

${ }^{26} 7 \mathrm{Wm}$. IV and I Vict., c. $26, \S \mathrm{XI}$ (1837).

${ }^{17} 7$ and 8 Geo. V, c. 58 (IgI8).

${ }^{88}$ For other statutory developments in England see: 28 and 29 Vict., c. 72 (1865); 60 and 6I Vict., c. I5 (r898); 20 and 2I Geo. V, c. 38 (r93I); 2 and 3 Geo. VI, c. 87 (r939).

19 Bordwell, The Statute Law of Wills, I4 Iowa L. Rev. $x, 29-30$ (x928).

${ }^{20}$ Atkinson, op. cit. supra note 7 ; Summers, op. cit. supra note 3 ; Whitlow, Wills-Two Phases of the Law of Military Testaments, 8 Mo. L. Rev. 59 (I943); I37 A.L.R. I3IO.

${ }^{2 x}$ Atkinson, op. cit. supra note 7 .

22 Digest 27.I3.I (I).

23 Mich. Stat. Ann. (Henderson, I937) § 26.1066.

34 Warren v. Harding, 2 R.I. I33 (1852); In the Goods of M'Murdo, [1867] I P. \& D. 540. 
One of the real legal battlegrounds in this field has been the meaning of the phrase, "actual military service." Most of the state statutes use this phrase, but there is disagreement as to its meaning. In Van Deuzer v. Gordon ${ }^{25}$ the testator, while in training camp in Massachusetts in $\mathrm{x} 862$, had executed a written instrument purporting to be his will. The writing was defective as a formal will and probate was requested as a valid soldier's will. In denying probate because the testator was not "in actual military service" at the time he made the will, the court said: "The term service in its restricted sense, is the exercise of military functions in the enemy's country in time of war, or the exercise of military functions in the soldier's own state or country in case of insurrection or invasion, and in this sense the words of the statute, 'actual military service,' should be understood. ... . The exception of the statute, in respect to soldiers' wills, is founded upon the necessity of the case. It is limited to cases where from the actual or supposed situation of the soldier he is exposed to the perils incident to actual warfare. ${ }^{26}$ In Pierce $\%$. Pierce ${ }^{27}$ an informal will, made just before the testator's departure for the place at which he was to be mustered into service, was held invalid, because the testator was not yet in "actual military service." An informal will, made by a soldier while on detached service away from his brigade during the Civil War, was held to be a valid soldier's will, although the testator was under no orders to move toward the front nor was he engaged in actual combat. ${ }^{28}$ The court said: "That there must be actual warfare, in the prosecution of which the soldier is at the time engaged, is clear." 29 It went on to say: ".... the soldier must be engaged in an actually existing warfare, and not merely belong to a garrison or standing army not employed in hostile operations." ${ }^{30}$ But the court later declared: "The term expedition is not to be confined to that movement of troops which immediately precedes the actual conflict and shock of battle." ${ }^{31}$ In Gould v. Safford's Estate ${ }^{32}$ an oral testament, made by a soldier while a patient in a field hospital during the Civil War, was admitted to probate where the testator had been on active combat duty and was in extremis at the time he made the will. A recent New Jersey case holds that an informal will, made by an inductee while on an induction furlough prior to reporting for active duty, is not a valid soldier's will..$^{33}$

The English courts have taken a broader view of the term "actual military service." In a case arising out of the Boer War the testator was held to be "on active military service," within the meaning of the statute, although he was in India at the time he made the will, expecting, however, to receive mobilization and movement orders to embark for Africa in the near future, and, in fact, did

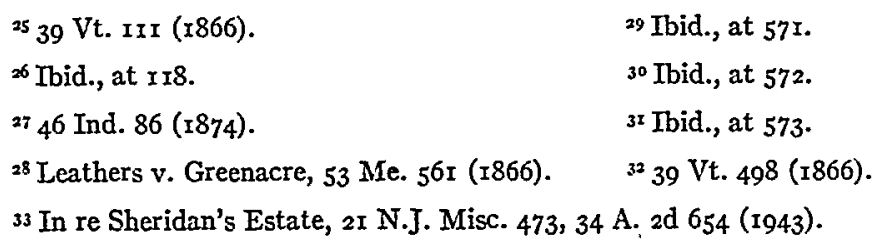


so embark within ten days. ${ }^{34}$ The informal will of a soldier, made while in camp in England in 1940, was held to be a valid soldier's will in In the Estate of $J$. King Spark. ${ }^{35}$ But the same court also decided in I94I that a dental corps officer, regularly assigned to a post of duty in England, but living in his usual home, was not in military service even though his home was struck by an enemy bomb and he was killed. ${ }^{6}$

Almost as fertile a breeding place for litigation have been the issues of who is a "seaman or mariner" and what is the meaning of "at sea." Any member of the crew of a merchant or naval vessel is included within the privilege. ${ }^{37}$ Even a stenographer regularly assigned to a passenger ship has been held to be within the term seaman..$^{8}$ There is a conflct as to whether the seaman must be employed as such at the time he makes the informal will, or whether it is valid even if he is only a passenger at the time. In Warren v. Barding, ${ }^{39}$ the court said: "The meaning of these words is a seaman employed as such at sea."

"At sea" is often held to mean tidal waters. Thus, in Gwinn's Will4" an informal testament made by a naval officer aboard a gunboat opposite Vicksburg, Mississippi, was denied probate because the testator was not "at sea." This decision apparently leads to the anomalous result that a soldier besieging Vicksburg by land can make an informal testament, but naval personnel besieging the same city from the river cannot. There is some authority for the proposition that when a ship has left the wharf and is under way toward its destination, it is "at sea," irrespective of whether it is in the ebb and flow of the tide. . $^{\mathrm{T}}$

The imprecise language of the statutes and the confusion concerning the history of the privilege have given rise to litigation as to what minimum age requirements are attached to the execution of informal wills by soldiers and seamen. Under Roman law any soldier or seaman could avail himself of the privilege regardless of age. $4^{2}$ The extreme unlikelihood of anyone under the age of puberty being in the army or navy made minimum age requirements unnecessary. This has been confusing to some courts seeking a solution to the problem in the Roman law background. In the early common law fourteen was the mini-

34 Gattward v. Knee, [I902] P. 99; and see Hiscock's Goods, [I9oI] P. 78, where the testator was in England expecting to receive orders to move to Africa.

35 [1941] P. II5.

${ }^{36}$ In the Estate of Gibson, [I94I] P. II8.

37 Ex parte Thompson, 4 Brad. (N.Y.) 154 (1854).

${ }^{3}$ In the Goods of Sarah Hale, [I9I5] 2 I.R. $3^{62 .}$

392 R.I. I33 (1852). Contra: In the Goods of Daniel Saunders, [1865] I P. \& D. 16.

$4^{\circ}$ I Tuck. (N.Y.) 44 (1865).

45 Summers, op. cit. supra note 3. But see Warren v. Harding, supra note 24. In this connection it is interesting to note the case of In the Goods of M'Murdo, [1867] I P. \& D. 540, where a seaman aboard a ship tied up in Portsmouth Harbor was held to be "at sea."

42 Ulpian 20.12. 
mum testamentary age in England. ${ }^{43}$ Although the Wills Act of $1837^{44}$ fixed twenty-one as the minimum testamentary age, the wording was such that English courts construed it to mean that soldiers' and seamen's wills were completely outside the scope of the act and not subject to this minimum age provision. 45 The Wills Act of $19 r 8^{46}$ provided that soldiers and seamen should be exempt from minimum testamentary age requirements. In the United States there has been a clear split on this point. In Henniner's Estate, ${ }^{47}$ the court found that the exception for soldiers' and seamen's wills in the Pennsylvania Statute of Wills of I833, which contained the words "notwithstanding this act," made the minimum age requirements for the execution of such wills fourteen, thus excepting soldiers' and seamen's wills from the statute. The opposite view was taken in Goodell v. $P i k e, 4^{8}$ which held that the exception in favor of soldiers did not apply to all the requirements of the act, but only to the formalities of execution, and that twenty-one was therefore the minimum age requirement. ${ }^{49}$

It was the essence of the Roman law on military testaments that no form was required.." A soldier "on expedition" could make a valid testament by writing in blood on his shield, or by tracing with his sword in the sand, or by oral instructions or in any other manner capable of proof. Although Swinburne declares this also to be the law in England, ${ }^{5 x}$ and although many cases have reaffirmed the rule both there and in the United States, ${ }^{52}$ there is at least one startling decision the other way in New York. ${ }^{53}$ The New York statute ${ }^{54}$ required a written will to be subscribed by two witnesses and permitted only soldiers and seamen to make oral wills of personalty. In this case a soldier on active service had written a letter containing testamentary instructions but not witnessed by two witnesses as required by the statute. The court denied probate, stating that the letter did not meet the statutory requirements either for a formal written will or an oral soldier's will. Two witnesses were required by

43 Swinburne, op. cit. supra note 1 , at pt. II. § 2.

44 $7 \mathrm{Wm}$. IV and I Vict., c. 26, \& XI (1837).

${ }_{45}$ In re Wernher, [IgI8] 2 Ch. 82 (C.A.).

${ }^{46} 7 \& 8 \mathrm{Geo}$. V, c. $58, \S_{3}$ (IgI8). "In order to remove doubts as to the construction of the Wills Act of 1837 , it is hereby declared and enacted that section eleven of that act authorizes and always has authorized any soldier being in active military service, or any mariner or seaman being at sea, to dispose of his personal estate as he might have done before the passing of the Act, though under twenty-one years."

${ }^{47} 30 \mathrm{~Pa}$. Dist. $4 \mathrm{I}_{3}$ (192x).

$4^{8} 4$ O Vt. 3 19 $(1867)$.

49 Accord: In re Evans' Will, I93 Iowa I240, I88 N.W. 774 (I922).

so Gaius 2.r14.

${ }^{5 x}$ Swinburne, op. cit. supra note I, pt. I, at § 14 .

52 Leathers v. Greenacre, 53 Me. $56 \mathrm{I}$ (I866); Gould v. Safford, 39 Vt. 498 (1866).

53 In the Matter of Zaiac's Will, 279 N.Y. 545 , 18 N.E. 2 d 848 (x939).

si N.Y. Dec. Est. Law (McKinney, I939) c. I3, § 2 I. 
the Roman law for proof of a soldier's or seaman's informal will, 55 and a similar requirement was enforced in English ecclesiastical courts even after the Statute of Frauds..$^{6}$ Most modern statutes are silent as to proof, but it is generally held that common law rules of evidence apply to probate matters. ${ }^{57}$ The point is seldom discussed in the cases, but a reasonable inference seems to be that in the absence of statute only one witness is required..$^{88}$

Most of the statutes limit the soldiers' and seamen's privilege to the disposition of personal property. ${ }^{59}$ As previously indicated, the Wills Act of IgI8 in England extended the privilege to real property. When an informal will attempts to dispose of both real and personal property, the entire will has been struck down if the two dispositions are not separable without defeating the testator's intention..$^{60}$

Revocation of and by informal testaments has presented perplexing problems. Generally, when statutes provide that a change of status, such as marriage plus issue, will revoke a formal will, the same rule is applied to informal soldiers' wills. The usual statutory methods of revoking a written will, such as burning, tearing, or obliteration apply equally to informally written soldiers' wills. ${ }^{6 x}$. In England it has been held that a soldier's letter instructing that his duly attested will be destroyed is a valid soldier's will and revokes the earlier formal will. ${ }^{62}$ Most American courts, however, have construed the statutes to mean that a duly attested will may be revoked by a subsequent instrument only if the latter is in regular attested form. ${ }^{63}$ Since there is no convincing authority in the United States for the proposition that informal soldiers' and seamen's wills are automatically revoked after the expiration of a certain period after discharge, ${ }^{64}$ in those states where a minor can make an oral soldier's will he may be unable to rid himself of that will except by marriage and, in some states, the birth of issue. Being unable to destroy an oral will and being too young to make a valid formal will, his only means of revocation before reaching twenty-one is by a change of status.

From the foregoing it seems clear that there is lack of uniformity among the various jurisdictions and that in modern times the military privilege doctrine

55 Digest 22.5.x2.

${ }^{56} 3$ Burn, Ecclesiastical Law 304 (9th ed., I842).

577 Wigmore, Evidence $\$ 2032-50$ (3d ed., r940).

${ }^{8}$ Gould v. Safford, 39 Vt. 498 (1866); Atkinson, op. cit. supra note 7, at 756. But see In the Matter of Zaiac's Will, 279 N.Y. 545, r8 N.E. 2d 848 (1939) and In re Evans' Will, I93 Iowa I240, I88 N.W. 774 (I922).

59 Bordwell, op. cit. supra note I9.

${ }^{60}$ Godman v. Godman, [r920] P. 26r.

6x In re Booth, [I926] P. II8.

6 Estate of Gossage, [r92I] P. I94 (C.A.).

${ }_{63}$ Devisees of McCune v. House, 8 Ohio I44 (I837); Allen v. Huff, 9 Tenn. 404 (I83O);

Brook v. Chappell, 34 Wis. 405 (1874).

${ }^{64}$ Whitlow, op. cit. supra note 20. 
is a poor tool for the accomplishment of its purpose. As stated in Rice v. Freeland, "The attitude is prevalent that to allow soldiers to make wills without meeting statutory requirements is a fitting reward for their services." The justification for the privilege is questionable. It is to be wondered whether this "privilege" is not really now more of a disservice to the soldier than a boon. Formal requirements for the execution of an ordinary will are imposed to protect the testator, his devisees, and legatees from fraud and mistake in the disposition of the estate. A doctrine permitting such disposition without safeguards against fraud, dishonesty, and loss of memory, and depending chiefly upon the moral restraint and responsibility of a witness to effect the intended distribution, does not commend itself.

It no longer seems necessary to place soldiers and seamen in a special class with regard to testamentary formalities. With the decline of illiteracy and in view of the current paternalistic attitude of the War and Navy Departments, soldiers and sailors now have ample opportunity to seek and obtain free legal advice and to execute wills with the prescribed formalities. During the last war, the War and Navy Departments extended every assistance to service personnel in the handling of their personal affairs. But the lack of uniformity among the states in the requirements for the execution of wills ${ }^{66}$ indicates the magnitude of the task imposed upon legal assistance officers trying to aid soldiers from every state in the preparation of wills. Not only is it necessary for the legal adviser to look up the law of the soldier's domicil, but often he must also see that the will meets the statutory requirements in the state where the testator owns real property. With millions in service in the last war the task imposed on military legal advisers was costly in time and produced unsatisfactory results. With no provisions for ante mortem probate or certification, the proof of an army-drawn will may be costly and difficult when witnesses are widely scattered.

If it be granted that the soldiers' and seamen's privilege of making informal wills is no longer necessary in modern times and that it is a dangerous, poorly fashioned tool for the transmission of wealth, it seems clear that the task of legal advisers to service personnel in time of emergency, when our military forces are swelled to huge numbers, must be made easier and their work more effective. A uniform, modern statute applicable to service personnel in time of emergency would accomplish the desired results.

The first hurdle to surmount is the question of the constitutional authority of Congress to enact a federal military wills act applying to all service personnel and effective to pass property in every state ${ }^{67}$ The analogies to the Soldiers and Sailors Civil Relief Acts of $19 \mathrm{I} 8$ and 1940 are apparent. ${ }^{68}$ Both acts covered all

${ }^{65}$ I3I Va. 298, I09 S.E. I86 (I92I).

${ }^{66}$ Bordwell, op. cit. supra note 19 .

${ }^{67}$ "I believe a federal military wills act could be enacted within the Constitution and much good would be accomplished thereby." Atkinson, op. cit. supra note 7, at 757 .

${ }^{68}{ }_{40}^{\circ}$ Stat. 440 (rgr8), 50 U.S.C.A. App. IoI (Supp., I946); 54 Stat. II 78 (I940), 50 U.S.C.A. $\S 5$ or et seq. (I944). 
service personnel and afforded the protection of mortgage foreclosure moratoria, postponement of lawsuits, restraints on levy of execution against certain property, and restraints on collection of state taxes by sale of property. Both were upheld as a constitutional exercise of the powèrs granted by Article $I$, Section 8 of the federal Constitution. ${ }^{69}$ State courts have unanimously recognized their validity and have abided by their provisions even to the derogation of conflicting state statutes. ${ }^{70}$

The I9r8 Act was a wartime measure, but the ${ }^{-} 940$ Act was enacted before the United States was engaged in war, yet it too was sustained as a valid exercise of the "war powers" and the power to levy armies." In indicating the scope of legislation which is encompassed within the powers granted in Article I, Section 8 of the Constitution, the courts seem to have made it a reasonable inference that a federal military wills act would be sustained. Judge Schwellenbach in United States v. Alberts" said, "If morale of the troops has the significance attached to it by the military, there is a direct relationship between the object sought by this statute and the means used in attaining it."73

Certainly the mental anxiety of soldiers and sailors concerning the support and welfare of their dependents and the disposition of their property after death is a factor in the morale of troops. The great need for simplicity and uniformity is an additional reason in support of the proposed legislation. The comments of Justice Rosenberry, speaking for the Wisconsin Court in Konkel v. State, ${ }^{74}$ seem particularly significant: "The orderly administration of affairs of the Army and Navy requires that such regulations [relating to service of civil process] should be uniform. The military and administrative officers of the United States ought not to be required to look into the statute books of fortyeight separate states to determine what the privileges and immunities of United States soldiers are."

The following draft statute is submitted as a proposal for uniform treatment of military wills. It is followed by detailed discussion of each section.

\section{PURPOSE:}

In order to provide for, strengthen, and expedite the defense of the United States and the more successfully to prepare for, prosecute, and carry on any war in which it is, or may become engaged, provision is hereby made for the execution of last wills and testaments of persons in the military and naval service of the United States in order to enable such persons to devote their entire energy to the defense needs of the nation, and to enhance the morale of troops, and to this end the following provisions are made:

${ }^{69}$ See Ebert v. Poston, 266 U.S. 548 (r925).

$7^{\circ}$ Hoffman v. Charlestown Five Cents Savings Bank, 23I Mass. 324, I2x N.E. I5 (IgI8); Pierrard v. Hoch, 97 Ore. 71, 79, rgr Pac. 328 (r920).

${ }^{1}$ Boone v. Lightner, 3 I9 U.S. 56r (I943).

${ }^{72} 59$ F. Supp. 298 (Wash., I945).

${ }^{73}$ Ibid., at 300 ; see also Chief Justice Stone's opinion in Hirabayashi v. United States 320 U.S. 8I (I943).

${ }^{74}$ I 68 Wis. 335,342 , r7o N.W. 715, 7r8 (rgrg). 


\section{DEFINITIONS:}

A. The term "persons in military service" and the term "persons in the military service of the United States," as used in this Act, shall include the following persons and no others: All members of the Army of the United States, the United States Navy, the United States Marine Corps, the United States Coast Guard, the United States Merchant Marine, all officers of the United States Public Health Service detailed by proper authority for duty with the Army or the Navy, and all United States civilian personnel serving with any of the armed forces of the United States outside the continental limits of the United States.

B. The term "military service" and the term "active-military service," as used in this Act, shall signify federal service at full pay and allowances with any branch of the service heretofore referred to or mentioned, and shall include the period during which a person in military service is absent from duty on account of sickness, wounds, leave, furlough, or other lawiul cause.

C. The term "courts," as used in this Act, shall signify courts of law and equity, including probate courts, of the United States, of the several states and territories, the District of Columbia, and all territories subject to the jurisdiction of the United States.

\section{TIME of AppLICATION:}

The provisions of this Act shall be in force only during the time of a national emergency, as declared by the Congress. Upon a declaration by the Congress that a state of national emergency exists, the provisions of this Act shall immediately become effective and shall continue in effect until the Congress declares that the period of emergency no longer exists. However, the preceding sentence shall not be construed to invalidate a will executed under the provisions of this Act while in effect, but offered for probate after the Act has ceased to be in effect.

\section{TERrITORIAL APPLICATION:}

A will properly executed under the provisions of this Act shall be valid to pass both real and personal property and shall be admitted to probate by any court in every state and territory of the United States, the District of Columbia, and every territory subject to the jurisdiction of the United States, local rules, decisions, or statutes to the contrary notwithstanding.

\section{Capactiy of the Testator:}

Every person in the active military service of the United States, irrespective of age or sex, who is of sound mind and memory, shall have the power to devise and bequeath by will the real and personal property, wherever situated, which he has at the time of his death.

\section{ForM OF THE WriL:}

Every will executed under the provisions of this Act shall be reduced to writing, shall be signed by the testator or by some person in his presence and at his request, and shall be signed and attested to in the presence of the testator by two or more competent witnesses, after the testator has, in their presence, declared the instrument to be his last will and testament, and has requested them to sign.

\section{CERTIFICATION:}

After the execution of a will, as provided herein, the testator and the attesting witnesses may appear before a commissioned officer, authorized by proper authority to administer oaths. If, upon inspection of the will and examination of the parties, the 
officer is satisfied that the will was properly executed according to the provisions of this Act; and that it represents the true intentions and desires of the testator; and that it is his free and voluntary act; and that the parties are of sound mind and memory; and that the witnesses are of the opinion that the will represents the true intentions and desires of the testator; and that it is his free and voluntary act; and that he is of sound mind and memory; then the officer shall prepare affidavits to the effect and cause the witnesses, under oath, to subscribe to the same their names, organizations, and home addresses. The officer shall then execute and sign a written certificate setting forth the facts as to his inspection of the will, his examination of the parties, and his findings; and he shall then place this certificate, together with the affidavits and the will, in a sealed envelope marked, "Will of (name), Confidential," and he shall place it in a separate file in the unit safe or other secure place where classified documents may properly be kept.

A will so placed shall thereafter be accessible only to the testator upon proper application to the officer in charge of the classified files of the unit: Upon transfer or reassignment of the testator the will shall be placed in a sealed envelope along with the testator's personnel records and he shall be instructed to deliver it, unopened, to his new commanding officer. Each commanding officer, upon receipt of a records envelope containing the will of newly assigned personnel, shall immediately remove the envelope containing the will and place it in the unit safe or other secure place where classified documents may properly be kept.

Upon the discharge of the testator or his release from active military service his will, together with the affidavits and certificate, shall be returned to him at the time he receives his discharge papers or orders of release from active military service.

Upon the death of the testator or upon his being reported as missing while in active military service, the envelope containing his will, executed in accordance with this Act, shall be forwarded at once by his unit commander to the War or Navy Department, as the case may be; and such Department shall, without delay, forward the envelope by registered mail to the person indicated by the testator as the person to be notified in case of emergency.

\section{PROOF OF WILI:}

The affidavits and certificate attached to the will, as required by the provisions of this Act, shall, in any court, be prima facie evidence of the competency of the testator and the witnesses, and of the proper and valid execution of the will. Clear and convincing proof shall be necessary to rebut the presumptions of competency and validity, and, in the absence of such clear and convincing proof, the will shall be admitted to probate.

IX. SCOpe of Application of Local Law:

Except as herein otherwise provided, the rules, decisions, and statutes of the state or territory in which the will is offered for probate shall, with respect to I) construction and interpretation, 2). dower and indefeasible share, 3) intestacy, 4) administration, 5) procedure, 6) conservation, 7) executors and administrators, 8) guardians, 9) will contests, IO) investments, and II) other matters not covered by this Act, govern and be applied to wills executed under the provisions of this Act; except that no local rule, decision, or statute shall be effective to alter, change, or defeat the distribution of property indicated in a will validly executed under the provisions of this Act, which does not make provision for any child or children whether born before or after the making of the will, provided that the entire net estate is left to the surviving spouse. 


\section{Revocation:}

A will made under the provisions of this Act shall automatically be revoked if the testator does not die within one year after discharge, or release from active military service. In addition, a will executed under the provisions of this Act may be revoked only I) by burning, tearing, or obliteration, by the testator or by some other person in his presence and at his request; 2) by a subsequent instrument, executed in accordance with the provisions of this Act and declaring the revocation; 3 ) by a subsequent instrument, executed in accordance with the requirements for the making of a will of the law of the testator's domicil at the time of execution and declaring such revocation; 4) by a subsequent will executed either in accordance with this Act or the law of the testator's domicil at the time of execution, to the extent such subsequent will is inconsistent with the prior will; 5) by marriage of the testator after execution of the will.

\section{LIBERAI INTERPRETATION:}

In the construction and application of the provisions of this Act a liberal interpretation shall be enforced so as to accomplish the purposes set forth in the Act. Local rules, decisions, and statutes conflicting with the provisions of this Act shall not be effective with respect to wills executed in accordance with this Act.

Section I indicates the power under which the act is passed and sets forth its purpose- to enhance the morale of the troops and to facilitate administration of the armed forces. Section II attempts to resolve the conflict in the cases as to when a soldier or seaman is "in active military service." It sets forth the test of full pay status to determine whether a person is in active military service. Of course, forfeiture of pay under sentence by courts martial will not operate to exclude a soldier from the benefits of the act. Since inductees and reservists are officially in the service from the date of their taking the oath, but are not on full pay status until called to active duty, they would not be included within the act until reporting for active service. This result is essentially the same as is reached under most of the cases. ${ }^{75}$

In Section III the operation of the act is limited to the time of national emergency as proclaimed by the Congress. In time of peace the armed forces will not be so large and problems of administration will not be so acute. The peacetime forces are composed chiefly of volunteers, who enter upon their service with deliberation, and therefore have ample opportunity to make provisions for their personal affairs. Furthermore, peacetime duty is much less hazardous and the urgency of making a will is not so great. Special provision is made to protect wills executed under the act while it is in force but which are offered for probate after the emergency has been declared at an end.

The act is given widespread coverage by Section IV, which makes the act applicable in every state and territory. This section also makes it clear that the act shall be binding in all states to pass both real and personal property, and establishes the supremacy of the act over conflicting state laws.

Section V removes the age requirement for testators in service; all service personnel should be included within the provisions of the act, even though they

75 In re Sheridan's Estate, 2 I N.J. Misc. 473, 34 A. 2 d 645 (I943). 
may be under the usual testamentary age. Many state statutes have now fixed eighteen as the minimum testamentary age, ${ }^{76}$ but occasionally persons have been successful in enlisting in the armed services although they were below the minimum age for induction. These persons, often engaged in hazardous duty, should be permitted to dispose of their property by will just as their older comrades do.

At a time when literacy is the rule, it seems no longer necessary to make special provisions for oral or informal wills by soldiers and sailors. The greater safety and protection afforded by a written will and the possibility of adopting blank forms for the majority of cases, seem to dictate the requirement of a written will, the customary requirements for which are set forth in Section VI. In connection with the certification procedure it is deemed advisable to require the testator to indicate to the witnesses that the instrument is his will and that he request them to sign. This procedure will be recited in the affidavits filed with the will.

An important feature of the act is Section VII, which provides for certification or something like ante mortem probate. In time of war, persons from all parts of the country are thrown together, and wills executed with attesting witnesses who live in distant parts of the country may be difficult and expensive to probate. As a protection against this, and to insure against the loss of memory and the attempts of the unscrupulous to try to "break" the will, certification procedure is provided. Essentially it is like the procedure for ante mortem probate suggested by Professor Cavers. ${ }^{77}$ After the testator and the witnesses have signed the will in the prescribed manner, they recite their procedure to an adjutant, summary court officer, or other officer authorized to administer oaths. If he is satisfied as to the form and execution of the will, he has the witnesses swear to the facts in an affidavit and then prepares his own certificate as to his conclusions. In case the procedure has been incorrect he directs that the will be reexecuted. If he is not satisfied as to capacity or freedom of the testator, he refuses to certify. The affidavits and certificate are prima facie proof of the validity of the will and this proof is to be recognized by every court. The will can be contested, but can be upset only upon clear and convincing proof of fraud, undue influence, incapacity, or misstatement of fact. Provision is made for the testator to remake his will at any time, and it will accompany him until discharge. The will is classified as "confidential," and a receipt will be obtained by the transmitting organization; thus it will be easier to locate the will if it becomes lost in military channels. In order to coordinate casualty reports with the forwarding of the will to the proper person upon death of the testator while in service, the will is channeled through the highest echelon.

The act is intended to cover the great majority of situations where the testa-

${ }^{6}$ Ill. Rev. Stat. (1945) c. 3.

7 Cavers, Ante Mortem Probate: An Essay in Preventive Law, I Univ. Chi. L. Rev. $44^{\circ}$ (I934). 
tor merely wants a simple will leaving all his property to one relative or a few close relatives. This is the situation in the majority of soldiers' wills and therefore presents the greatest administrative problems. A few stock forms for the majority of cases will expedite this work. The testator with complicated problems of estate planning should not seek advice on such problems from legal aid officers. His needs can best be served by a personal attorney. By and large such a testator can usually afford to employ counsel. In view of these considerations the act is not a comprehensive probate act. The statutes of the testator's domicil will govern the questions not specifically covered by this act. The only case requiring special attention is that of the military testator who wishes to leave his entire estate to his spouse, who is then expected to care for the children, if any. Some statutes permit a child to take its intestate share if not provided for or mentioned in the will. This frequently involves the expense of guardianships and other inconveniences which can be sidestepped in most cases. ${ }^{78}$

In connection with revocation it has been thought advisable to include a provision, similar to the one found in the Roman law, revoking the will unless the testator dies within one year after discharge. The changed conditions and attitudes which occur upon release from military service and the possibility of forgetting about the military will after discharge seem to dictate that a military will should not continue in effect an unduly long time. The usual statutory methods may also be used to revoke the soldier's will, and since the testator has easy access to his will throughout his service, he can readily rid himself of it.

It is submitted that the proposed statute warrants serious consideration both as a means of insuring the high morale of troops and as a means of discharging one of the nation's responsibilities to its soldiers and sailors.

EDWIN A. WABLEN*

${ }^{8}$ Mathews, Trends in the Power to Disinherit Children, I6 A.B.A.J. 293 (I930).

* J.D., University of Chicago Law School. 